\title{
低炭素鋼燒なまし材の塑性ひずみ繰返し応力ーひずみ曲線の解析*
}

$$
\begin{aligned}
& \text { 平修 二** 後藤徹*** } \\
& \text { 黒部利次****葛西 靖 正 }{ }^{* * * * *}
\end{aligned}
$$

\section{A Study on Cyclic Stress-Strain Relation in Annealed Low Carbon Steel}

\author{
by \\ Shuji TAIRA \\ (Faculty of Engineering, Kyoto University, Kyoto) \\ Toru GOTO \\ (Mitsubishi Heavy Ind., Ltd., Akashi) \\ Toshitsugu KuROBE \\ (Faculty of Engineering, Kanazawa University, Kanazawa) \\ and Yasuaki KASAI \\ (Daido Steel Co., Ltd., Nagoya)
}

The stress-strain behavior of annealed low carbon steel under cyclic straining was investigated, and the results obtained are as follows.

(1) Under cyclic straining of constant total strain ranges of 2,3 and $4 \%$, the stress range increased with the increase in cyclic number. On the other hand, it decreased when the mean strain of $10 \%$ was applied. However, the stress range had a tendency to saturate with increase of cycles in both cases.

(2) The stress $\sigma^{\prime}$-plastic strain $\varepsilon_{p}^{\prime}$ relation in half cycle with the reference point at the tip of hysteresis loop was found to be composed of two linear portions on log-log plotting. The relation was described in the form of

$$
\left.\sigma^{\prime}=K^{\prime}\left\{\frac{2 \varepsilon_{p 0}^{\frac{\alpha_{1}-\alpha_{2}}{2}}-2}{\pi} \tan ^{-1}\left(\frac{\varepsilon_{p}^{\prime}-\varepsilon_{p 0}{ }^{\prime}}{a}\right)+\varepsilon_{p o}{ }^{\frac{\alpha_{1}-\alpha_{2}}{2}}\right\} \varepsilon_{p}^{\prime}{ }^{\prime} \frac{\alpha_{1}-\alpha_{2}}{\pi} \tan ^{-1}\left(\frac{\varepsilon_{p}^{\prime}-\varepsilon_{p 0}{ }^{\prime}}{p}\right)+\frac{\alpha_{2}+\alpha_{1}}{2}\right\}
$$

where $\alpha_{1}$ and $\alpha_{2}$ are the strain hardening exponents according to the relation of plastic strain in value whether large or small respectively. $\quad \varepsilon_{p o}{ }^{\prime}$ is the plastic strain dividing the plastic strain in the semi-cycle into two portions.

(3) Strain range and the number of cycles seem to have little effect on the values of $\alpha_{1}$, $\alpha_{2}$ and $\varepsilon_{p o}^{\prime} . \alpha_{1}$ and $\alpha_{2}$ were about 0.18 and 0.08 , respectively, and the former was about twice as large as the latter. $\varepsilon_{p o}{ }^{\prime}$ was in $0.6-0.9 \%$. The mean strain produced larger value of $\alpha_{2}$ in the semi-cycle of straining reverse to the mean strain in its direction.

(4) The two different strain hardening exponents found in the semi-cycle may indicate that the elasto-plastic deformation occurs before plastic deformation during the semi-cycle.

(5) In the saturated hysteresis-loop shape of stress-strain at various strain range, the stress range and plastic strain range was related as follows;

with $\alpha_{0}$ of 0.19 .

$$
\Delta \sigma=K_{0} \Delta \varepsilon_{p}^{\alpha_{0}}
$$

(Received June 5, 1971)

\footnotetext{
* 本報を「X線による繰返し塑性変形の研究 (第 1 報)」(X-Ray Study on Cyclic Deformation of Metals, I) とする 原稿受理 昭和46年 6 月 5 日

** 正 会 員 京都大学工学部 京都市左京区吉田本町

*** 正 会 員 三菱重工(株)神戸研究所 明石市魚住町清水字北次

**** 正 会員 金伬大学工学部 金冯市小立野

***** 正会員 大同製鋼 名古屋市南区大同町
}

\section{1 緒言}

繰返しひずみを受ける材料の塑性変形挙動は, 繰返 乙数とともに变化し，またその応力・ひずみ曲線が七

ステリシス・ループ状となる事からも明らかなように, 一方向の変形挙動を観察する引張試験等では説明され 
得ない種々特徴を持っている。それゆえ, 動的荷重を 受けるのが普通である現実構造部材の応力解析, 塑性 ひずタ範囲さらにはひずタエネルギによる疲学累積損 傷表示, あるいは現在盛んとなった破壞力学による疲 労き裂伝ぱの取り扱い, 等に䞌いては繰返し下ての応 力とひずみの関係を定量的には握しておく事が必要で ある。また, 疲労の問題に打ける塑性変形は特にさ裂 発生に関し, 単に力学的取扱いのみならず, 機構学的 にもその役割が明らかにされつつあって, 繰返し変形 に関する微視的機構的な追求は疲労破壞機構研究の一 つの大きな分野といえる。

これら諸点を挙げてみても繰返し下の塑性変形に関 する幅の広い研究が望まれる。そこで筆者らは, 繰返 し変形挙動を巨視的に観察するとともに, X線回折法 による変形時の結晶組織の変化を観察し, 繰返し下の 塑性变形に関して二, 三の考察を行なった. 本報告に 牤いては，S15C 低炭素鋼完全焼なむし材の引張り。

圧縮定ひずみ繰返し下に括ける塑性変形挙動について 記すが，ひきつづき，X線回折による観察結果を報告 する予定である.なお, 観察した繰返し下の塑性変形 は平均ひずみのない場合および $10 \%$ 引張りの平均ひず みがある場合で，与皇全ひずみ範聿は $2 \sim 4 \%$ あ る。

\section{2 ひずみ繰返し条件下の変形挙動の表示}

Fig. 1 に, 任意の繰返し変形を与えた場合の応力一 ひずみ曲線を模式的に図示した。同図で, 繰返し半サ イクル（M回目のそれは除荷開始点 $O^{\prime}(M)$ から始ま り $\mathrm{O}^{\prime}(M+1)$ で終了するとする) に注目してみると， 応力範囲 $\Delta \sigma$, 全ひずみ範囲 $\Delta \varepsilon$, 塑性ひずみ範囲 $\Delta \varepsilon_{p}$ そして平均ひずみ $\varepsilon_{\text {mean }}$ は図中に示されるごとくに 定義される。

繰返乙変形挙動を観察する場合, $\Delta \varepsilon$ (あるいは $\Delta \varepsilon_{p}$ ) を一定に保ちながら(1) $\Delta \sigma$ の繰返し数に対する変化に 注目する. (2) $\Delta \sigma$ は繰返し数の少ない初期に大きく変 化するが後定常化する傾向を示す場合が多いので, 定 常期に拈いて $\Delta \sigma$ 対 $\Delta \varepsilon$ (あるいは $\Delta \varepsilon_{p}$ ) の関係を明ら

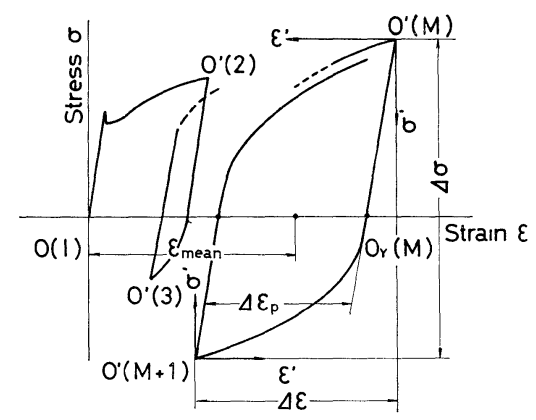

Fig. 1. Schematic stress-strain diagram of cyclic deformation.
かにせんとする, あるいは(3)繰返し半サイクルの応 力ーひずみ曲線の形自体に注目する，等が考光られる。

本研究に和いては, 変形の機構的追求に意図がある ので，(3)の方法を採用し，Fig. 1 に和いて $O^{\prime}$ 点を原 点とする $\sigma^{\prime \prime}-\varepsilon^{\prime}$ 座標系をあたえて繰返し变形下の応力ー ひずみ曲線 (以後繰返し応力ーひずみ曲線之称する) を解析してみた。な拈, 本論文で用いられる応力は真 応力である.ひずみは絶対值が大きくないので公称ひ ずみを用いた。

\section{3 実 験 方 法}

\section{$3 \cdot 1$ 試験片}

試験片素材の化学組成抒よび機械的性質を Table I に示す. 試験片はFig. 2 に示す形状に機械加工後, $950^{\circ} \mathrm{C} 30$ 分間の真空焼な皂しを行ない，さらにネシ部 以外飞電解研摩を施こして加工層・脱炭層を除去した。

Table I. Chemical composition and mechanical properties of testing material(wt \%).

\begin{tabular}{|c|c|c|c|c|c|c|c|c|}
\hline $\mathrm{C}$ & $\mathrm{Mn}$ & $\mathrm{S}_{1}$ & $\mathrm{P}$ & S & $\mathrm{Cu}$ & $\mathrm{N}_{1}$ & $\mathrm{Cr}$ & $\mathrm{Fe}$ \\
\hline 016 & 043 & 016 & 013 & 029 & 008 & 002 & 004 & $\mathrm{Bal}$ \\
\hline \multicolumn{9}{|c|}{ Mechanical properties of testing material } \\
\hline \multicolumn{5}{|c|}{ Tensile strength } & \multicolumn{4}{|c|}{$405 \mathrm{~kg} / \mathrm{mm}^{2}$} \\
\hline \multicolumn{5}{|c|}{ Yield stress } & \multicolumn{4}{|c|}{$268 \mathrm{~kg} / \mathrm{mm}^{2}$} \\
\hline \multicolumn{5}{|c|}{ Elongation } & \multicolumn{4}{|c|}{$434 \quad \%)$} \\
\hline \multicolumn{5}{|c|}{ Reduction of area } & \multicolumn{4}{|c|}{$685 \%$} \\
\hline
\end{tabular}

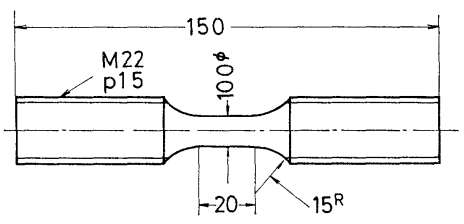

Fig. 2. Test specimen.

\section{$3 \cdot 2$ 塑性ひずみ繰返し試験}

ひずみ繰返しは，室温で全ひずみ制御による引張り ・圧縮を与えた。用いた試験機は, ダイ・セットを改 造した試験片保持装置を島津製作所製オートグラフ IS-5000のクロスヘットと台座間に組み入れたもので ある、ひずみ測定は，抵抗線ひずみゲージを用いた島 津製エ.クステンソィータを使用した。エクステンソメ 一タの標凖標点間長さは $15 \mathrm{~mm}$ である. 試験機主要 部分ならびにェクステンソメータを試験片に装着した 状態をFig. 3 に示す。，荷重一伸び曲線は，Fig. 3 に示 される荷重計ならびにェクステンソメータの出力を増 幅器を通じて X-Y 記録計に自記させた。なお, 繰返 乙速度は，クロス・ヘッド速度一定下のもとで約 2 $3 \mathrm{cpm}$ であった。

Fig. 4 に, 破壊繰返し数を示す。点は平均ひする 


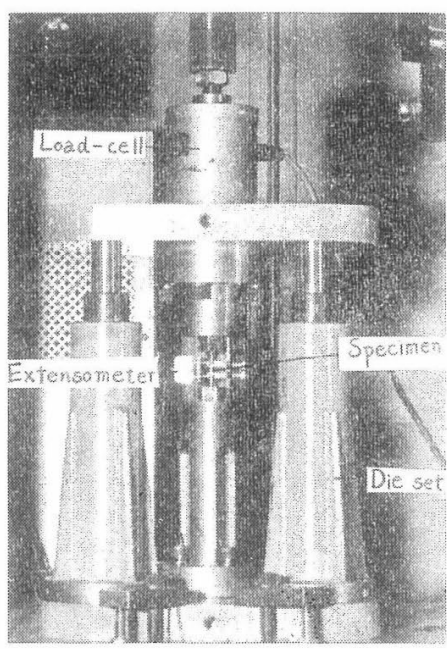

Fig. 3. Main parts of testing machine.

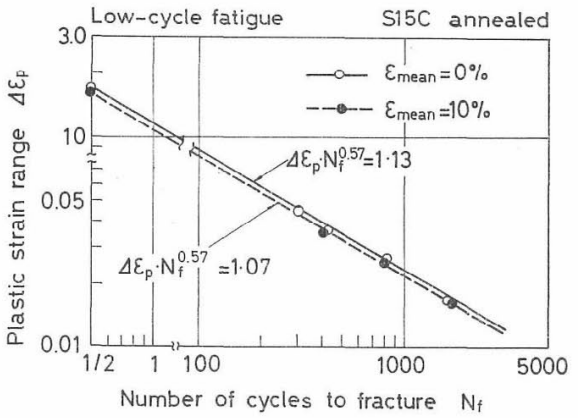

Fig. 4. Plastic strain range-life plot.

のない場合，点は10\%引張平均ひずみ艺与えた場合 の結果である，完全破断繰返し数 $N_{f}$ と， 1/2 $N_{f}$ で算 出した塑性ひずみ範囲 $\Delta \varepsilon_{p}$ の間には，図中で示される ごと艰係式 (Manson-Coffin 式) が求められた。

\section{4 实 験 結 果}

$4 \cdot 1$ 応力範囲の繰返し数に伴う变化

Fig. 5 に，平均ひずみ０\%㧍よび10\%引張り家与亮 た場合の各ひず範囲繰返し過程に括ける応力範囲 $\Delta \sigma$ の変化を繰返し数 $n$ に対して表示する。同図より 明らかなごとく平均ひずみが０の場合， $\Delta \sigma$ は繰返し 数の増加と之もに急增して後その增加割合は減少する 傾向が認められる。一方，平均ひずみがある場合， $\Delta \sigma$ は繰返し数亡ともに急隇するが，やがてその減少割合 は少なくなって，過程の大半に抦いてほぼある值を保

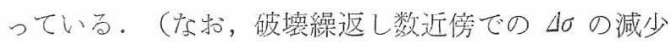
はき裂の内部進展による有效断面穦の減少を意味して いる.)

これら，繰返し条件下での応力範围变化な，それぞ れ“繰返しひずみ加工硬化あるいは軟化とそれらの定 常化”として良く認められている事実で岁る。Fig. 5 苃又るとわかるように，本実験に就いては，必ずしも

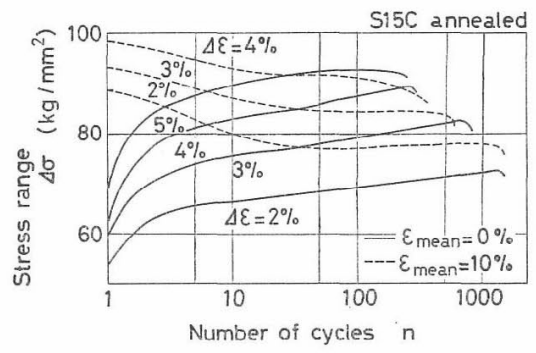

Fig. 5. Variation of stress range during low-cycle fatigue.

明確な定常期（ $\Delta \sigma$ がー定となる時期）の存在光認め る亨はできなかった。

\section{$4 \cdot 2$ 繰返し变形下の応力ーひずみ曲線}

Fig. 6 に，平均ひずみ $\varepsilon_{\text {mean }}$ が $0 \%$ ，全ひずみ範囲 $\Delta \varepsilon j^{3} 4 \%$ 場合定例に之って各 $M$ に和ける $\sigma^{\prime}-\varepsilon^{\prime}$ 座 標系での応力ーひずみ曲線を両対数で示してみる。同 図で $\varepsilon^{\prime} か ゙$ 約 $0.15 \%$ 以下では各 $M$ の $\sigma^{\prime}-\varepsilon^{\prime}$ 曲線は重な って和りまた $\varepsilon^{\prime}=0.1 \% て ゙ の \sigma^{\prime}$ は大略弾性常数より 求められる值 $21 \mathrm{~kg} / \mathrm{mm}^{2}$ となった。气こで, Fig. 1 に説明されている $O_{Y}(M)$ 点より始まる塑性ひずる $\varepsilon_{p}^{\prime}$ に刘する $\sigma^{\prime}$ の挙動を観察し以下実験結果を整理 した。

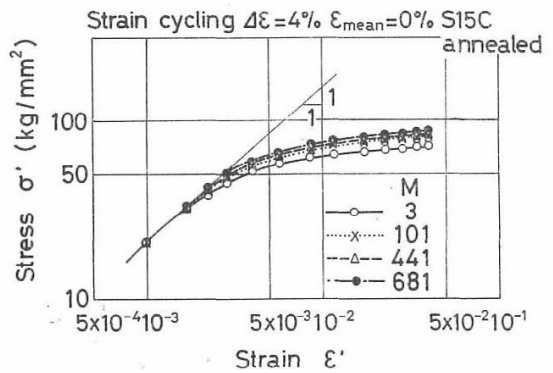

Fig. 6. Stress-strain behavior under strain range of $4 \%$ without mean strain.

$4 \cdot 2 \cdot 1$ 平均ひずみが0の場合 Fig. 7 K，Fig. 6 で示した $\varepsilon_{\text {mean }}=0 \%, \Delta \varepsilon=4 \%$ の結果を $\sigma^{\prime}-\varepsilon_{p}^{\prime}$ 曲線 で表わす。 Fig. 6 と比較すると明らかなように, 両対 数図上で $\sigma^{\prime}-\varepsilon_{p}{ }^{\prime}$ 曲線は折狆曲った 2 本の直線部分で 近似構成されるよ5になった。4・1 で述べた“繰返 し加工硬化とその定常化” は，Fig. 7 に打いては，M の増加とともに $\sigma^{\prime}-\varepsilon_{p}^{\prime}$ 曲線が棌ぼ平行に上方に移行し やがて定着する現象として表罖されている。

Fig. 7 で示した $\sigma^{\prime}-\varepsilon_{p}^{\prime}$ 曲線は，圧縮荷重の除荷から 開始する半サイクルの場合であるので，M值は奇数と なっている、 $M$ な $M+1$ に打るる $\sigma^{\prime}-\varepsilon_{p}^{\prime}$ 曲線の差違は, リニーダース変形の進行が認められる $M$ の極く小さい 場合を除いて，半サイクルごとに生じてゆく加工硬化 の進行による差以外，次に述べる平均ひずみのある場 


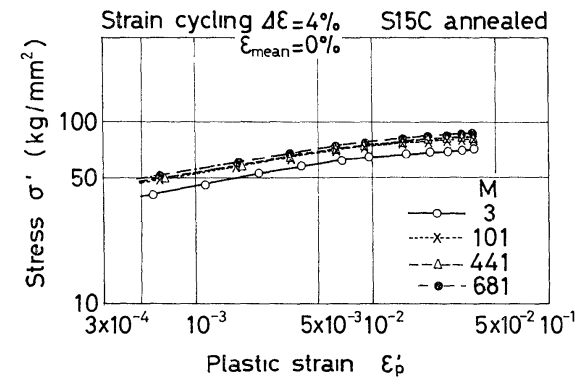

F1g. 7. Plastic stress-strain behavior under strain range of $4 \%$ without mean strain.

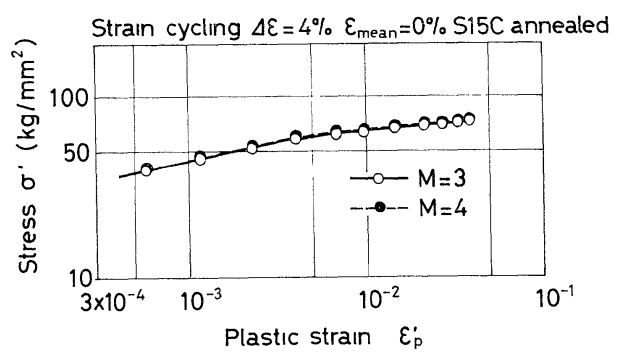

Fig. 8 Plastic stress-strain behavior of $M=3$ and 4 under strain range of $4 \%$ without mean strain.

合のような顕著な差違は認められなかった。Fig. 8 亿, $M=3$ 抢よび 4 の $\sigma^{\prime}-\varepsilon_{p}^{\prime}$ 曲線を示して扔く.

以上の現象は, $\Delta \varepsilon=3$ 打よび $2 \%$ の場合にも共通に 認められた。

$4 \cdot 2 \cdot 2$ 平均ひずみとして $10 \%$ 引張りを与えた場 合 Fig. 9 亿, $\varepsilon_{\text {mean }}=10 \%, \Delta \varepsilon=4 \%$ の場合の結果を, $M$ が奇数の場合について示す. 同図にても明らかなよ 5 亿, $\sigma^{\prime}-\varepsilon_{p}{ }^{\prime}$ 曲線は, 平均ひずみの無い場合之同様, 両対数上で近似的に 2 本の直線部分で構成されらるよ らである。大きい平均ひずみ下に拈いて認められる “繰返し加工軟化とその定常化” は，Mの増加ととも に $\sigma^{\prime}-\varepsilon_{p}^{\prime}$ 曲線が下方に移行しやがて定着する現象とし

て Fig. 9 では表現されている.

Fig. 10 飞, $M=11$ 㫟よび12の $\sigma^{\prime}-\varepsilon_{p}{ }^{\prime}$ 曲線を示す。 同図にみられるよ5亿，雨者の形には顕著な差がある

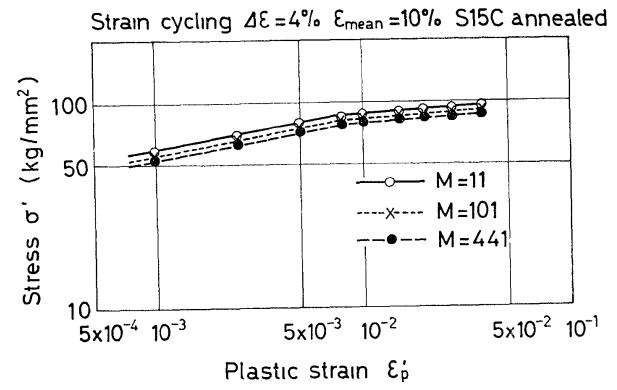

Fig. 9. Plastic stress-strain behavior under strain range of $4 \%$ with $10 \%$ mean strain.

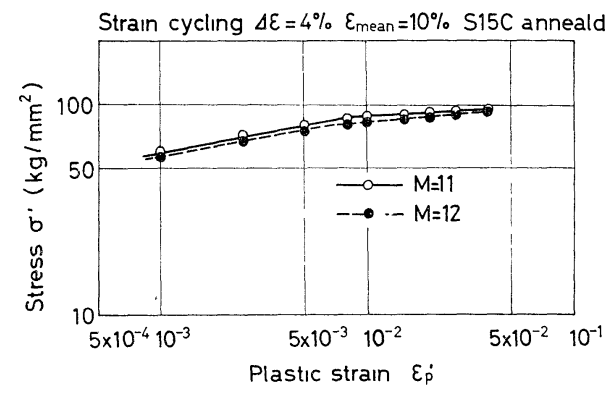

Fig. 10. Plastic stress-strain behavior of $M=11$ and 12 under strain range of $4 \%$ with $10 \%$ mean strain.

が，両者の差は主に $\varepsilon_{p}^{\prime}$ が大きい領域に持汁る $\sigma^{\prime}-\varepsilon_{p}^{\prime}$ 曲線の傾き汇認められるようである。平均ひずみ方向 之逆方向変形 ( $M$ が偶数) での上記傾きは同方向での そ机比べてかなり大きい。これら応力ーひずみヒス テリシス・ループの非対称性は, 次節で示すように繰 返し数の增加とともに消失する傾向は認められるよう であったが，定常期炕入ってをと非対称性はかなり 大きかった。

$4 \cdot 2 \cdot 3$ 繰返し下の塑性変形における 加工硬化係 数 前項で示したように, 除荷開始点を原点とする繰 返し下の真応力-塑性ひずみ曲線は両対数図上で折れ 曲った 2 本の直線部分から構成されるようである。そ こで，Fig. 11 亿図解するように， $\sigma^{\prime}-\varepsilon_{p}^{\prime}$ 曲線を $\varepsilon_{p}^{\prime}$ の 小さい領域 1 と大きい領域 2 飞分将, 沶の拈のの領域 に打省近似直線の傾きからそれぞれの領域での加工 硬化係数 $\alpha_{1}$ 拈よび $\alpha_{2}$ を求めた。測定した結果を $\varepsilon_{\text {mean }}=0 \%$ 扮よび10\%の場合に分けて Table II 立 とめた。同表で, $\varepsilon_{p o}{ }^{\prime}$ は, Fig. 10 亿示されているよ 弓汇両領域の境界塑性ひずみを示す。

Table II の結果から，Fig. 12 亿 $\alpha_{1}$ の值を破断恋 での繰返し半サイクル数 $M_{f}$ 汇対する半サイクル数比 $M / M_{f}$ を横軸にとりプロットした。同眓よりみて, $\alpha_{1}$ は 0.15〜0.20の間でばらついて拉り, $M / M_{f}$ や ひずみ範囲あるいは平均ひずみに対する依存性は認め 難い. Fig. 13 に $\alpha_{2}$ のプロットを示す。 $\varepsilon_{\text {mean }}=10 \%$ でMが偶数の場合, ひずみ範团や $M / M_{f}$ に対する依

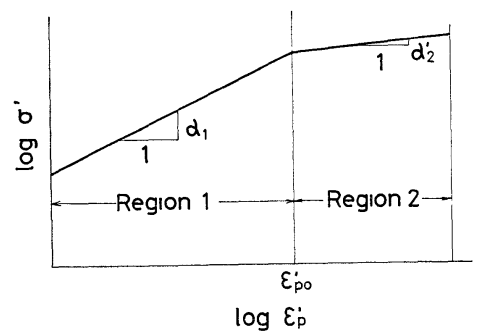

Fig. 11. Schematic illustration of plastic stressstrain relation in half cycle.

「材料」第21巻 第221号 
Table II. Plastic stress-strain properties under cyclic deformation.

\begin{tabular}{|c|c|c|c|c|c|c|c|c|c|c|c|c|c|c|}
\hline \multicolumn{5}{|c|}{$\varepsilon_{\text {mean }}=0 \%$} & \multicolumn{10}{|c|}{$\varepsilon_{\text {mean }}=10 \%$} \\
\hline$\Delta \varepsilon$ & $M$ & $\alpha_{1}$ & $\alpha_{2}$ & $\varepsilon_{0}^{\prime}(\%)$ & $\Delta \varepsilon$ & $M$ & $\alpha_{1}$ & $\alpha_{2}$ & $\varepsilon_{0}^{\prime}(\%)$ & $\Delta=$ & $M$ & $\alpha_{1}$ & $\alpha_{2}$ & $\varepsilon_{0}^{\prime}(\%)$ \\
\hline \multirow{4}{*}{$4 \%$} & 3 & 184 & 077 & 60 & \multirow{4}{*}{$\begin{array}{c}4 \% \\
(\mathrm{M}, \mathrm{Odd})\end{array}$} & 11 & 178 & .056 & 86 & \multirow{4}{*}{$\begin{array}{c}4 \% \\
\text { (M, Even) }\end{array}$} & 12 & 178 & 100 & .70 \\
\hline & 101 & .165 & 072 & .72 & & 101 & . 178 & .064 & 84 & & 102 & 170 & . 100 & .90 \\
\hline & 441 & .173 & 082 & .86 & & 201 & 175 & 063 & .78 & & 202 & .188 & .101 & .78 \\
\hline & 681 & .152 & 090 & 88 & & 441 & .172 & .076 & .92 & & 442 & .197 & 099 & .90 \\
\hline \multirow{4}{*}{$3 \%$} & 7 & .175 & 085 & .70 & \multirow{4}{*}{$\begin{array}{c}3 \% \\
(\mathrm{M}, \mathrm{Odd})\end{array}$} & 21 & .163 & .076 & 76 & \multirow{4}{*}{$\begin{array}{c}3 \% \\
(\mathrm{M}, \text { Even) }\end{array}$} & 22 & 172 & .110 & .77 \\
\hline & 201 & 150 & 090 & .88 & & 101 & 161 & .078 & 72 & & 102 & .170 & 109 & .90 \\
\hline & 521 & .173 & 073 & 86 & & 401 & .188 & .068 & .86 & & 402 & .183 & .086 & .94 \\
\hline & 781 & 160 & 090 & 86 & & 801 & .178 & 071 & 84 & & 802 & 181 & .102 & .88 \\
\hline \multirow{5}{*}{$2 \%$} & 23 & 175 & 085 & 60 & \multirow{5}{*}{$\begin{array}{c}2 \% \\
(\mathrm{M}, \mathrm{Odd})\end{array}$} & 21 & .178 & .084 & 60 & \multirow{5}{*}{$\begin{array}{c}2 \% \\
(\mathrm{M}, \text { Even })\end{array}$} & 22 & .179 & .138 & .85 \\
\hline & 201 & .188 & .078 & .75 & & 201 & .162 & .084 & .74 & & 202 & .200 & .101 & .76 \\
\hline & 601 & .190 & .090 & .75 & & 401 & .193 & .084 & .70 & & 402 & 192 & 102 & .72 \\
\hline & 1001 & .184 & .090 & .74 & & 1061 & 201 & .093 & .74 & & 1062 & 201 & .119 & .74 \\
\hline & 1601 & .200 & . 110 & .78 & & 1761 & . 183 & .110 & .68 & & 1762 & .200 & .118 & .76 \\
\hline
\end{tabular}

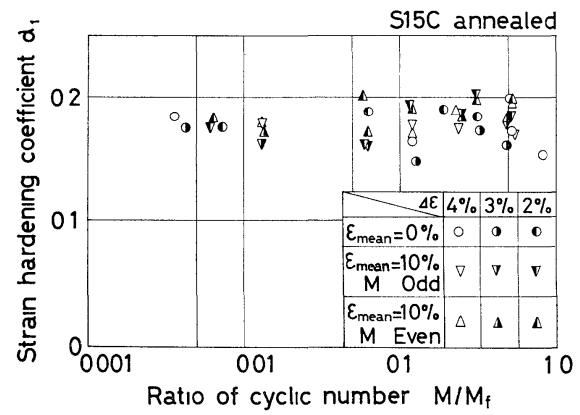

F1g. 12. Plotting of strain hardening coefficient in Region 1 versus ratio of cyclic number.

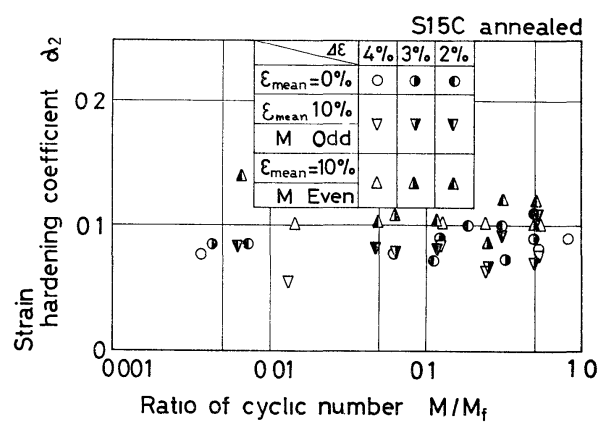

Fig. 13. Plottıng of strain hardening coefficient in Region 2 versus ratio of cyclic number.

存性は認め難く，また值も 0.1 以上となっているが， その他の場合には，概略，ひずみ範囲が小さい程また 繰返し数が多い程值が大きい傾向が認められるようで あり，值も0.1 以下となっている. $\alpha_{2}$ の值は， $\varepsilon_{\text {mean }}$ $=10 \%$ でMが偶数の場合を除くと， $\alpha_{1}$ の約 $1 / 2$ 程度の 值である. Fig. 14 に $\varepsilon_{p o}^{\prime}$ のプロットを示して乱く.

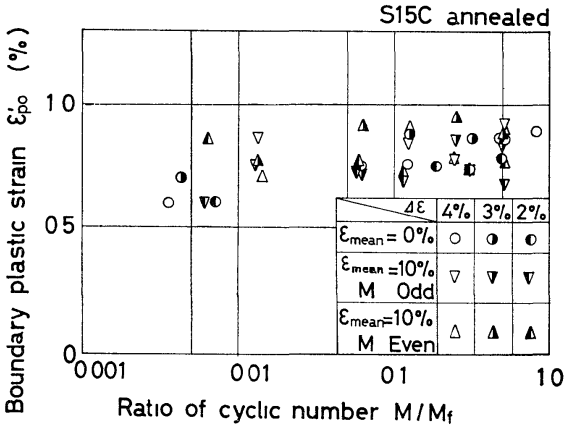

Fig. 14 Plotting of boundary plastic strain versus ratio of cyclic number.

$\varepsilon_{\text {mean }}=10 \%$ の場合には $M / M_{f}$ に対する依存性は認め 難いが， $\varepsilon_{\text {mean }}=0 \%$ の場合繰返し初期に急増する傾向 が認められた。ひずみ範囲依存性についてみると,ひ ずみ範囲が大きい程全般的に $\varepsilon_{p o}^{\prime}$ 值も大きいようであ る.值は $0.6 〜 0.9 \%$ 内にあった。

$\alpha_{2}$ あるいは $\varepsilon_{p o}^{\prime}$ の，ひずみ範囲あるいは繰返し数 に対する依存性は，乙かしながら，測定值のばらつき から考劣てそれ程大きいとはい充ないようである。

\section{5 考察}

$5 \cdot 1$ 繰返し変形下の応力ーひずみ関係式

一般に多結晶金属の引張変形に拈ける応力ーひずみ 曲線は次式で表示されることが多い.

$$
\sigma=K \varepsilon_{p}{ }^{\alpha}
$$

ここでKは強度係数， $\alpha$ は加工硬化係数と称されてい る. 繰返し变形定常期に打ける応力ーひずみヒステリ シスループの形は加工履歴の効果が消失するので材料 固有の性質を表わしやすいと考光られている。 Morrow 等は定常期の応力範囲 $\Delta \sigma$ 対塑性ひずみ範囲 $\Delta \varepsilon_{p}$ 
のプロットを行ない， $K_{0}$ 和よび $\alpha_{0}$ を材料常数とし て $\Delta \sigma$ と $\Delta \varepsilon_{p}$ の間に次式が成立すると報告している.

$$
\Delta \sigma=K_{0} \Delta \varepsilon_{p}{ }^{\alpha}{ }_{0}
$$

そこで， $\sigma^{\prime}-\varepsilon_{p}^{\prime}$ 曲線と(2)式の関係を見るため, 結果の 内 $\varepsilon_{\text {mean }}=0 \%$ シリーズで $M$ のもっとも大きい場合 をFig. 15 に再プロットしてみた。 $\Delta \sigma-\Delta \varepsilon_{p}$ 曲線は $\sigma^{\prime}$ $\varepsilon^{\prime}{ }_{p}$ 曲線群の先端を結儿で得られることは容易にわか る、な伺园に, 二, 三他の試験結果もあわせ付記し たが，それらは先端点の及を記入した。同図に示した 一点鎖線は，本実験結果の(2)式的表示である。これよ り $\alpha_{0}$ として 0.19 なる值が求められた。

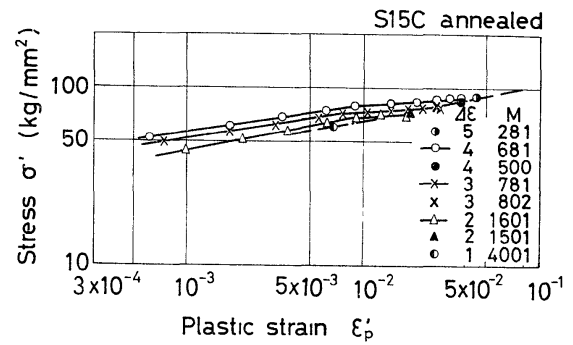

Fig 15 Plastic stress-strain behavior at saturation stage.

前章にて示したが， $\sigma^{\prime}-\varepsilon^{\prime}{ }_{p}$ 曲線の加工硬化係数は領 域 1 と2で異なって抢り， $\varepsilon_{p o}^{\prime}$ 以下の領域に打けるそ

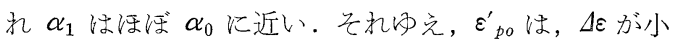
さい程小さくなるようではあるが，その $\Delta \varepsilon$ 依存性は 少ないので, $\Delta \varepsilon$ が $0.7 \%$ 近傍の值をとる $\varepsilon_{p o}^{\prime}$ 以下で は $\sigma^{\prime}-\varepsilon_{p}^{\prime}$ 曲線が(2)式と注注合致すると考光られる。乙 かしながら， $\Delta \varepsilon$ が $\varepsilon_{p o}^{\prime}$ より大きくなると(2)式のごと き単純な表現式でもって $\sigma^{\prime}-\varepsilon^{\prime}{ }_{p}$ 関係情わし得ない. そこで, $\Delta \varepsilon$ が $\varepsilon_{p o}^{\prime}$ よりも大さい場合も含めて, 繰返 し変形下の応力ーひずみ関係を次式のごとく表示して みた。

$$
\begin{gathered}
\sigma^{\prime}=K^{\prime} A \varepsilon_{p}^{\prime B} \\
A=\frac{2 \varepsilon_{p o}^{\prime} \frac{\alpha_{1}-\alpha_{2}}{2}-2}{\pi} \tan ^{-1}\left(\frac{\varepsilon_{p}^{\prime}-\varepsilon_{p o}^{\prime}}{a}\right)+\varepsilon_{p o}^{\prime} \frac{\alpha_{1}-\alpha_{2}}{2} \\
B=\frac{\alpha_{2}-\alpha_{1}}{\pi} \tan ^{-1}\left(\frac{\varepsilon_{p}^{\prime}-\varepsilon_{p o}^{\prime}}{a^{\prime}}\right)+\frac{\alpha_{2}+\alpha_{1}}{2}
\end{gathered}
$$

ここで $K^{\prime}$ は領域 1 の関係を(2)式で， $\Delta \sigma$ のかわりに $\sigma^{\prime}$ を， $\Delta \varepsilon_{p}$ のかわりに $\varepsilon_{p}^{\prime}$ を，そして $\alpha_{0}$ のかわりに $\alpha_{1}$ を代入して表現した場合の $K_{0}$ に相当する。 $a$ 抢よび $a^{\prime}$ は, $\varepsilon_{p o}^{\prime}$ 近傍で害験值と(2)式による推定傎との近似 度を示す量となるが, 小さくとればとる程 2 本の直線 部分による近似に漸近する。な拈 Moreenは，1100 A1 の場合に扮ける $\sigma^{\prime}-\varepsilon_{p}^{\prime}$ 曲線の両詨数上プロットを

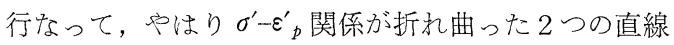
部分で表わせることを見い出しているが，かれはとの 関係を(3)式とは異なった式で表現している。

\section{$5 \cdot 2$ 繰返し条件下の変形機構について}

これまてに示したように，繰返し条件下のもとでの 応力一望性ひずみ曲線を解析してみると, 繰返し半サ イクルの変形範囲注塑性ひずタが $0.7 \%$ 近傍を境にし て加工硬化係数の異なる 2 つ領域に分けうるようで あった．Moreen はこの現象を転位論的観点から説明 している. 繰返し塑性変形は可動転位の単純な往復運 動（shuttling）によるとするWatt の考光方を引用 し，かれは逆方向に外力が変わると今まてに移動した 方向への pile up によるバックストレスは逆方向䔟動 を容易にさせるが，そのような効果が顕著である領域

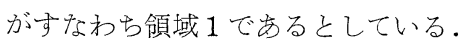

しかしながら，このような多結晶体の塑性変形挙動 を論じる場合，変形の基本的機構として抽出すべき転 位挙動とともに多結晶体としての特徵を無視すること はできないと考えられる。すなわち，多結晶体に抏い ては，(1)方位の違いにもとつく結晶粒間のすべりやす さや加工硬化係数の違い，(2)結晶粒界で互いに接する 結晶粒相互の変形拘束等がその変形挙動を支配する重 要な因子であるとされている。そこで，多結晶体をす ベりやすさは異なるが, 他の諸性質は等しい 2 つの要 素A 抢よびBから構成されているとする，各要素の応 力ーひずみヒステリシス・ループをFig. $16(\mathrm{a}) \sim(\mathrm{d})$ に細 線で示されるごとくに仮想してみる。すると，太線で 示すような多結晶体のヒステリシス・ループを求める ことができよう。な拉，(a)执よび(b)以両要素がひずみ 一様で変形する場合执よび応力一様で変形する場合を それぞれ示している。それら変形拘束状態を示すモデ ルを各図右に描いた。(c)および(d)はAとBが同じすべ りやすさをもつけれども塑性変形領域に拉いて異なる 傾きの応力ーひずみ曲線を持つ場合で，それぞれひず み一様执よび応力一様変形を示している.すると Fig. 16 中太線で示されるように，(d)の場合や剛塑性体で 構成された多結晶体の場合等を除いて, 半サイクルに 和计る変形には弾性部分, 弾・塑性重合部分, 塑性部 分が生じ，応力-塑性ひずみ曲線でみるとまず傾さの 大きい部分が現われ次いでその傾きの小さい部分が生 じるといったように，2つの領域に区分される事にな ろう.この考察結果は, 実験結果を定量的に説明する 事はできないが，応力一塑性ひずみ曲線が加工硬化係 数の異なる, すなわち, 変形様相に何らかの差違のあ ると考えられる2つの領域から成立する事を定性的に しろ説明できよ 5 .

Moreenの考える転位の pile up によるバックスト レスは，Fig.16(a)あるいは(b)に和いて，一方向にす ベりやすい結晶粒がずへり後たと光転位密度の増加と ともに塑性変形しにくくなるとしても, 逆方向にはや はりずべやすい性質を持つとした事の良い説明とな 


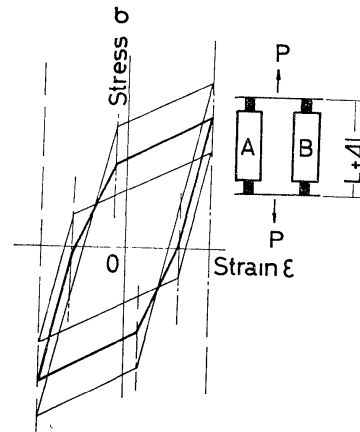

(a) Under uniform strain

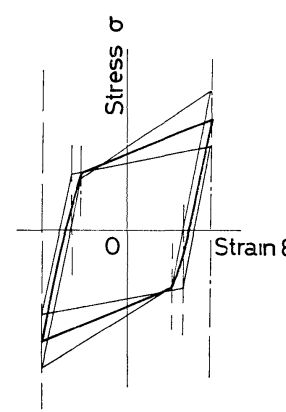

(c) Under unform strain (d) Under unfform stress Fig. 16. Cyclic deformation models.

りうると考えられる。

\section{6 結}

言

$\mathrm{S} 15 \mathrm{C}$ 焼なむ乙材を用いて, 平均ひずみの無い場合 拉よび10\%引張りを与えた場合の, 全ひずみ範囲一定 繰返し下にお打る変形挙動を観察して次の結果を得た。

(1) 全ひずみ範囲 2〜4\%の繰返しを与えると, 平 均ひずみの無い場合には “繰返し加工硬化”が生じ応 力範囲が増加するが繰返し数の増加とともに飽和する 傾向を示す． 10\%引張平均ひずみがある場合には “繰 返し加工軟化”を示し, 応力範囲は減少しやがてその 減少割合は少なくなって，過程の大半に执いて医ぼ る值を保つようになる。

（2）除荷開始点を原点として繰返し半サイクルの応 力 $\sigma$-塑性ひずみ $\varepsilon_{p}^{\prime}$ 曲線を両対数図上にプロットする と, 充分直線で近似しらる2つの部分に分けられた。 両部分の境界ひずみを $\varepsilon_{p o}^{\prime}$ として， $\varepsilon_{p}^{\prime}$ の小さい領域 に特ける加工硬化係数を $\alpha_{1}$, 大きい領域のそれを $\alpha_{2}$ とすると, $\sigma^{\prime}-\varepsilon^{\prime}{ }_{p}$ 曲数注次のごとくに数式化し得た。

$$
\sigma^{\prime}=K^{\prime} A \varepsilon^{\prime}{ }_{p}^{B}
$$

$$
\begin{aligned}
& A=\frac{2 \varepsilon_{p o}^{\prime} \frac{\alpha_{1}-\alpha_{2}}{2}-2}{\pi} \tan ^{-1}\left(\frac{\varepsilon_{p}^{\prime}-\varepsilon_{p 0}^{\prime}}{a}\right)+\varepsilon_{p 0}^{\prime} \frac{\alpha_{1}-\alpha_{2}}{2} \\
& B=\frac{\alpha_{2}-\alpha_{1}}{\pi} \tan ^{-1}\left(\frac{\varepsilon_{p}^{\prime}-\varepsilon_{p o}^{\prime}}{a^{\prime}}\right)+\frac{\alpha_{2}+\alpha_{1}}{2}
\end{aligned}
$$

（3）ひずみ範囲，繰返し数に対する依存性の系統た った変化の傾向は， $\alpha_{1}$ についてみると認められない が， $\alpha_{2}$ 特よび $\varepsilon_{p o}^{\prime}$ には存在するようであった。しか しながら，その依存度は大きくはない。な拉， $\alpha_{1}$ は 0.15〜0.20の間にばらついており, 平均值として0.18 程度の值を示すが， $\alpha_{2}$ は, 平均ひずみのある場合で 平均ひずみと逆方向に向かう半サイクル過程を除くと, 0.1 以下となり， $\alpha_{1}$ の約 $1 / 2$ 程度となった。 $\varepsilon_{p 0}^{\prime}$ は0. 6 〜0.9\%内にあった。

(4) 繰返し数比が $1 / 2$ 近傍以上の繰返し数領域に特い て, 応力範囲 $\Delta \sigma$ と塑性ひず範囲 $\Delta \varepsilon_{p}$ の間には次式 が成立するようであった。

$$
\Delta \sigma=K_{o} \Delta \varepsilon_{p} \alpha_{0}
$$

実験結果から $\alpha_{0}$ 公求めてみると, 約 0.19 の值が得ら れた。

(5) $\alpha_{1}$ および $\alpha_{2}$ といった加工硬化係数の異なる 2 つの領域が繰返し半サイクルの変形過程中に現われる 事は, 多結晶体の弾・塑性重合変形領域掞よび塑性変 形領域がその過程中に存在するためであると考光られ た。

（昭和46年 5 月 22 日 日本材籵学会第20期総会講演会にて講演）

\section{参考文 献}

1) Manson, S. S, "Thermal Stress and Low-Cycle Fatigue" (1966) McGraw-H1ll

2) Morrow, J., Theo. Appl. Mech Rep., No. 32, Univ. of I11. (1968).

3) Serensen, S. V., and R. M. Schnelderovitch, Proc. ASTM , 61, 789 (1961).

4) 白鳥英亮, 小幡谷洋一, 日本機械学会論文集, 35, 705 (1969).

5) Moreen, H A, Trans. ASME, Series D, 126 (1970).

6) Jaoul, B., “金属の塑性” (1969) 丸善

7) Feltner, C. E, and C Laird, Acta Met., 15, 1621 (1967).

8) Watt, D. F, and R. K. Ham, Nature, 211, 734 (1966).

9) Cottrell, A. H., "Dislocations and Plastic Flow in Crystals," Oxford Univ. Press. (1953). 